\title{
An Analysis of the Components of Superstitions Behavior and Will to Win in Basketball Performance
}

\author{
Nishan Singh Deol ${ }^{1}$, Davinder Singh ${ }^{2}$ \\ ${ }^{1}$ Department of Physical Education, Punjabi University, Patiala, India \\ ${ }^{2}$ Department of Physical Education (T), Guru Nanak Dev University, Amritsar, India
}

Email address:

ds_rajput87@yahoo.in (D. Singh)

\section{To cite this article:}

Nishan Singh Deol, Davinder Singh. An Analysis of the Components of Superstitions Behavior and Will to Win in Basketball Performance. American Journal of Applied Psychology. Vol. 4, No. 5, 2015, pp. 129-136. doi: 10.11648/j.ajap.20150405.13

\begin{abstract}
The researcher of this study aim to know about the role of Superstitions Behavior and Will to Win in Basketball Performance. To obtain data, the investigator had selected Fifty $(\mathrm{N}=50)$ male inter-college level basketball players of Guru Nanak Dev University, Amritsar, Punjab were selected for this study. The purposive sampling technique was used to attain the objectives of the study. All the subjects, after having been informed about the objective and protocol of the study, gave their consent and volunteered to participate in this study. They were further divided into $(\mathrm{N}=10)$ each playing position i.e. Point guard $\left(\mathrm{n}_{1}=10\right)$, Shooting guard $\left(\mathrm{n}_{2}=10\right)$, Small forward $\left(\mathrm{n}_{3}=10\right)$, Power forward $\left(\mathrm{n}_{4}=10\right)$ and Center $\left(\mathrm{n}_{5}=10\right)$. To measure the level of superstitions behaviors of the subjects, the superstitions beliefs and behaviour scale constructed by Bleak and Frederick (1998) was administered. To measure the level of will to win was measured by applying will to win questionnaire prepared by Kumar and Shukla (1998). One way Analysis of Variance (ANOVA) was employed to find out the intragroup differences. Where F values were found significant LSD (Least Significant Difference) Post-hoc test was applied to find out the direction and degree of difference. For testing the hypotheses, the level of significance was set at 0.05 . In a nutshell it can be said that from the findings that significant differences were found in basketball players Point Guard, Shooting Guard, Small Forward, Power Forward and Center on the sub-variables of Superstitions Behavior i.e., Clothing and Appearance, fetish, Team Ritual and Superstitious (Total). However, insignificant differences had been observed in the basketball players Point Guard, Shooting Guard, Small Forward, Power Forward and Center on the sub-variables of Superstitions Behavior i.e., Preparation, Game/Competition, Prayer and Coach. Conculdingly from the above findings that insignificant differences were present in the basketball players on the variable of will to win.
\end{abstract}

Keywords: Superstitions Behavior, Will to Win, Basketball Players

\section{Introduction}

The origin of superstitions can be traced to beliefs people held, in the olden times. While most of them arise out of fear, some are meant to drive fear away. Superstitious beliefs are an outcome of ignorance and lack of rational thinking, but then they are beliefs after all. Beliefs become notions, then it became opinions, and then they begin to prevail in society as well as sports world. The validity of superstitions is based on belief in the power of magic and witchcraft and in such invisible forces as spirits and demons. It is a common occurrence in the sports world for an athlete to engage in superstitious behaviors that may seem odd to others. Society seems to mock athletes and believe that their behaviors are absurd; however, each superstition serves a purpose in which the sportsperson finds to be beneficial to their performance. Some top class athletes believe that their superstitions enhance their performance and alter the outcome of the competition, but in fact, practice and confidence is the key to success in athletics (Mayberry, 2010). Many sport psychologists view superstitions as nothing more than reactions that begin with conditioning and boosting a placebo effect (Roenigk, 2010). Wann et al. (2010) describe superstitious behavior as an action or series of actions believed to lead to or cause a specified, generally desirable, outcome. Brooks (2009) explains that people engage in superstitious behaviours when they feel as if they are losing control over their own lives and their brains are searching for order and structure. Cultural and environmental factors also play a role. For example, it has been found that persons in high risk areas in the Middle East, currently in a state of disarray, are more likely to carry a lucky charm in 
hopes of regaining some order and structure and reducing some of their internal chaos (Brooks, 2009). Most irrational beliefs have been associated with human helplessness in the face of insurmountable difficulties (Mailer and Lundeen, 1934). Some believe that superstitions and rituals are an attempt to manipulate fate and act as a psychological placebo to athletes (Robson, 2005). The most negative consequence that can occur from superstitions and rituals would be if the athlete were to abandon them; doubt, anxiety, and worry might escalate and performance may significantly suffer. In reality, if an athlete is unable to follow their rituals or superstitions, their focus may be hindered (Fogelman, 2013). Paul (1960) rightly remarked "A winner never quits and the quitters never win". That means if one has the desire to win surely wins. It indicates that where there is a will, there is a way. It is expressed by scientist that the ability to work to the capacity is directly related to will to win. There are instances of men lacking physical qualification of great boxers still they have won. Will to win is the intensity to desire to defeat an opponent or to excel some performance standard in a given sports. Therefore, the present study was designed with the purpose to investigate the superstitious behaviour and will to win in basketball players.

\section{Material and Methods}

\subsection{Selection of Subjects}

To obtain data, the investigator had selected Fifty $(\mathrm{N}=50)$ male inter-college level basketball players of Guru Nanak Dev University, Amritsar, Punjab were selected for this study. The purposive sampling technique was used to attain the objectives of the study. All the subjects, after having been informed about the objective and protocol of the study, gave their consent and volunteered to participate in this study. They were further divided into $(\mathrm{N}=10)$ each playing position i.e. Point guard $\left(\mathrm{n}_{1}=10\right)$, Shooting guard $\left(\mathrm{n}_{2}=10\right)$, Small forward $\left(\mathrm{n}_{3}=10\right)$, Power forward $\left(\mathrm{n}_{4}=10\right)$ and Center $\left(\mathrm{n}_{5}=10\right)$.

\subsection{Tools}

To measure the level of superstitions behaviors of the subjects, the superstitions beliefs and behaviour scale constructed by Bleak and Frederick (1998) was administered. To measure the level of will to win was measured by applying will to win questionnaire prepared by Kumar and Shukla (1998).

\section{Statistical Analysis}

One way Analysis of Variance (ANOVA) was employed to find out the intra-group differences. Where $F$ values were found significant, LSD (Least Significant Difference) Posthoc test was applied to find out the direction and degree of difference. For testing the hypotheses, the level of significance was set at 0.05 .

\section{Results}

It can be seen from table-1 that significant differences were found with regard to the sub-parameter Clothing and Appearance among basketball players (Point Guard, Shooting Guard, Small Forward, Power Forward and Center) as the P-value (Sig.) .01 was found smaller than 0.05 level of significance $(\mathrm{p}<0.05)$. Since the obtained F-value was found significant, therefore, least significant difference (LSD) Posthoc test was employed to study the direction and significance of difference between paired means among basketball players (Point Guard, Shooting Guard, Small Forward, Power Forward and Center) on the sub-parameter Clothing and Appearance. The results of LSD Post-hoc test have been presented in Table-2.

Table 1. Analysis of Variance (ANOVA) results among Point Guard, Shooting Guard, Small Forward, Power Forward and Center Male Basketball Players with regard to the sub-parameter Clothing and Appearance.

\begin{tabular}{llllll}
\hline $\begin{array}{l}\text { Source of } \\
\text { Variation }\end{array}$ & $\begin{array}{l}\text { Sum of } \\
\text { Squares }\end{array}$ & $\begin{array}{l}\text { Degree of } \\
\text { Freedom }\end{array}$ & $\begin{array}{l}\text { Mean } \\
\text { Square }\end{array}$ & F-value & $\begin{array}{l}\text { P-value } \\
\text { (Sig.) }\end{array}$ \\
\hline $\begin{array}{l}\text { Between } \\
\text { Groups }\end{array}$ & 330.88 & 4 & 82.72 & & \\
Within Groups & 659.30 & 45 & 14.65 & $5.64 *$ & .001 \\
Total & 990.18 & 49 & & & \\
\hline
\end{tabular}

Table 2. Analysis of Least Significant Difference (LSD) post hoc test among Point Guard, Shooting Guard, Small Forward, Power Forward and Center Male Basketball Players with regard to the sub-parameter Clothing and Appearance.

\begin{tabular}{|c|c|c|c|}
\hline Means & & Mean Difference & $\begin{array}{l}\text { P-value } \\
\text { (Sig.) }\end{array}$ \\
\hline \multirow{4}{*}{$\begin{array}{l}\text { Point Guard } \\
\text { [35.30] }\end{array}$} & Shooting Guard [28.70] & $6.60^{*}$ & .000 \\
\hline & Small Forward [33.30] & 2.00 & .249 \\
\hline & Power Forward [33.70] & 1.60 & .355 \\
\hline & Center [36.10] & -.80 & .643 \\
\hline \multirow{4}{*}{$\begin{array}{l}\text { Shooting } \\
\text { Guard } \\
{[28.70]}\end{array}$} & Point Guard [35.30] & $-6.60^{*}$ & .000 \\
\hline & Small Forward [33.30] & $-4.60^{*}$ & .010 \\
\hline & Power Forward [33.70] & $-5.00^{*}$ & .005 \\
\hline & Center [36.10] & $-7.40^{*}$ & .000 \\
\hline \multirow{4}{*}{$\begin{array}{l}\text { Small } \\
\text { Forward } \\
{[33.30]}\end{array}$} & Point Guard [35.30] & -2.00 & .249 \\
\hline & Shooting Guard [28.70] & $4.60^{*}$ & .010 \\
\hline & Power Forward [33.70] & -.40 & .816 \\
\hline & Center $[36.10]$ & -2.80 & .109 \\
\hline \multirow{4}{*}{$\begin{array}{l}\text { Power } \\
\text { Forward } \\
{[33.70]}\end{array}$} & Point Guard [35.30] & -1.60 & .355 \\
\hline & Shooting Guard [28.70] & $5.00^{*}$ & .005 \\
\hline & Small Forward [33.30] & .40 & .816 \\
\hline & Center [36.10] & -2.40 & .168 \\
\hline \multirow{4}{*}{$\begin{array}{l}\text { Center } \\
{[36.10]}\end{array}$} & Point Guard [35.30] & .80 & .643 \\
\hline & Shooting Guard [28.70] & $7.40^{*}$ & .000 \\
\hline & Small Forward [33.30] & 2.80 & .109 \\
\hline & Power Forward [33.70] & 2.40 & .168 \\
\hline
\end{tabular}

*Significant at 0.05

1. It has been observed from the table-2 that mean difference between point guard and shooting guard male basketball players was found 6.60. The P-value (Sig.) .000 showed that the point guard male basketball players had demonstrated significantly 
better Clothing and Appearance than their counterpart shooting guard male basketball players.

2. The mean difference between point guard and small forward male basketball players was found 2.00. The P-value (Sig.) .249 revealed that point guard had exhibited better Clothing and Appearance though not significantly than their counterpart small forward male basketball players.

3. The mean difference between point guard and power forward male basketball players was found 1.60. The P-value (Sig.) .355 revealed that point guard had exhibited better Clothing and Appearance though not significantly than their counterpart power forward male basketball players.

4. The mean difference between point guard and center male basketball players was found .80 . The P-value (Sig.) .643 revealed that center had exhibited better Clothing and Appearance though not significantly than their counterpart point guard male basketball players.

5. The mean difference between shooting guard and small forward male basketball players was found 4.60. The P-value (Sig.) .010 showed that the small forward male basketball players had demonstrated significantly better Clothing and Appearance than their counterpart shooting guard male basketball players.

6. The mean difference between shooting guard and power forward male basketball players was found 5.00. The P-value (Sig.) .005 showed that the power forward male basketball players had demonstrated significantly better Clothing and Appearance than their counterpart shooting guard male basketball players.

7. The mean difference between shooting guard and center male basketball players was found 7.40. The P-value (Sig.) .000 showed that the center male basketball players had demonstrated significantly better Clothing and Appearance than their counterpart shooting guard male basketball players.

8. The mean difference between small forward and power forward male basketball players was found .40 The P-value (Sig.) .816 revealed that power forward had exhibited better Clothing and Appearance though not significantly than their counterpart small forward male basketball players.

9. The mean difference between small forward and center male basketball players was found 2.80. The P-value (Sig.) .109 revealed that center had exhibited better Clothing and Appearance though not significantly than their counterpart small forward male basketball players.

10. The mean difference between power forward and center male basketball players was found 2.40. The P-value (Sig.) .168 revealed that center had exhibited better Clothing and Appearance though not significantly than their counterpart power forward male basketball players.

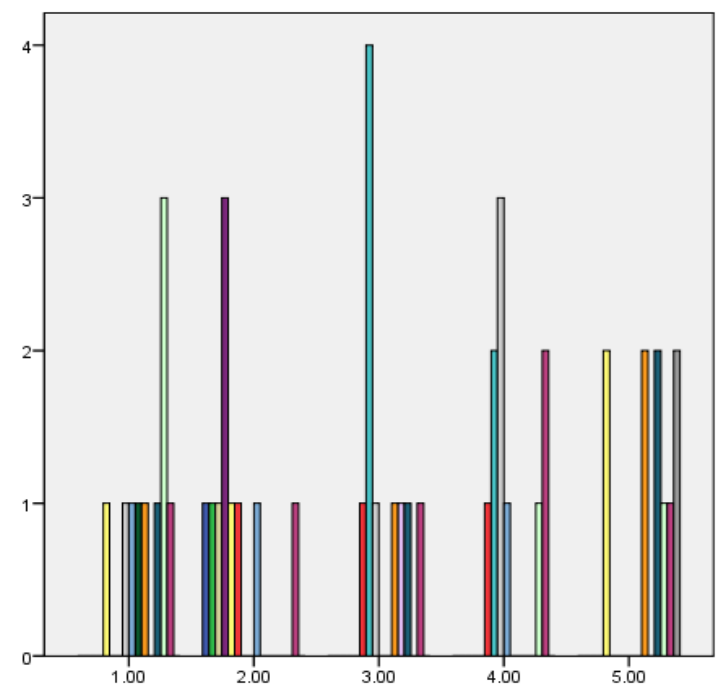

Figure 1. Graphical representation of mean scores with regard to Point Guard, Shooting Guard, Small Forward, Power Forward and Center Male Basketball Players with regard to the sub-parameter Clothing and Appearance.

Table 3. Analysis of Variance (ANOVA) results among Point Guard, Shooting Guard, Small Forward, Power Forward and Center Male Basketball Players with regard to the sub-parameter Fetish.

\begin{tabular}{llllll}
\hline $\begin{array}{l}\text { Source of } \\
\text { Variation }\end{array}$ & $\begin{array}{l}\text { Sum of } \\
\text { Squares }\end{array}$ & $\begin{array}{l}\text { Degree of } \\
\text { Freedom }\end{array}$ & $\begin{array}{l}\text { Mean } \\
\text { Square }\end{array}$ & F-value & $\begin{array}{l}\text { P-value } \\
\text { (Sig.) }\end{array}$ \\
\hline Between Groups & 115.72 & 4 & 28.93 & & \\
Within Groups & 461.80 & 45 & 10.26 & $2.81^{*}$ & .036 \\
Total & 577.52 & 49 & & & \\
\hline
\end{tabular}

Table 4. Analysis of Least Significant Difference (LSD) post hoc test among Point Guard, Shooting Guard, Small Forward, Power Forward and Center Male Basketball Players with regard to the sub-parameter Fetish.

\begin{tabular}{llll}
\hline Means & & Mean Difference & $\begin{array}{l}\text { P-value } \\
\text { (Sig.) }\end{array}$ \\
\hline \multirow{2}{*}{ Point Guard } & Shooting Guard [17.30] & 1.10 & .447 \\
{$[18.40]$} & Small Forward [17.90] & .50 & .729 \\
& Power Forward [15.00] & $3.40^{*}$ & .022 \\
Shooting & Center [19.60] & -1.20 & .407 \\
Guard & Point Guard [18.40] & -1.10 & .447 \\
{$[17.30]$} & Powall Forward [17.90] & -.60 & .677 \\
& Center [19.60] & -2.30 & .115 \\
Small & Point Guard [18.40] & -.500 & .115 \\
Forward & Shooting Guard [17.30] & .600 & .729 \\
{$[17.90]$} & Power Forward [15.00] & $2.90^{*}$ & .677 \\
& Center [19.60] & -1.70 & .049 \\
Power & Point Guard [18.40] & $-3.40^{*}$ & .242 \\
Forward & Shooting Guard [17.30] & -2.30 & .022 \\
{$[15.00]$} & Small Forward [17.90] & $-2.90^{*}$ & .115 \\
& Center [19.60] & $-4.60^{*}$ & .049 \\
& Point Guard [18.40] & 1.20 & .002 \\
Center & Shooting Guard [17.30] & 1.10 & .407 \\
{$[19.60]$} & Small Forward [17.90] & .50 & .115 \\
& Power Forward [15.00] & $3.40^{*}$ & .242 \\
\hline
\end{tabular}

*Significant at 0.05

It can be seen from table-3 that significant differences were 
found with regard to the sub-parameter Fetish among basketball players (Point Guard, Shooting Guard, Small Forward, Power Forward and Center) as the P-value (Sig.) .036 was found smaller than 0.05 level of significance $(p<0.05)$. Since the obtained F-value was found significant, therefore, least significant difference (LSD) Post-hoc test was employed to study the direction and significance of difference between paired means among basketball players (Point Guard, Shooting Guard, Small Forward, Power Forward and Center) on the sub-parameter Fetish. The results of LSD Post-hoc test have been presented in Table-4.

1. It has been observed from the table-4 that mean difference between point guard and shooting guard male basketball players was found 1.10. The P-value (Sig.) .447 revealed that point guard had exhibited better Fetish though not significantly than their counterpart shooting guard male basketball players.

2. The mean difference between point guard and small forward male basketball players was found .50. The P-value (Sig.) .729 revealed that point guard had exhibited better Fetish though not significantly than their counterpart small forward male basketball players.

3. The mean difference between point guard and power forward male basketball players was found 3.40. The P-value (Sig.) .022 showed that the point guard male basketball players had demonstrated significantly better Fetish than their counterpart power forward male basketball players.

4. The mean difference between point guard and center male basketball players was found 1.20. The P-value (Sig.) .407 revealed that center had exhibited better Fetish though not significantly than their counterpart point guard male basketball players.

5. The mean difference between shooting guard and small forward male basketball players was found .60 . The P-value (Sig.) .677 revealed that small forward had exhibited better Fetish though not significantly than their counterpart shooting guard male basketball players.

6. The mean difference between shooting guard and Power Forward male basketball players was found 2.30. The P-value (Sig.) .115 revealed that shooting guard had exhibited better Fetish though not significantly than their counterpart Power Forward male basketball players.

7. The mean difference between shooting guard and Center male basketball players was found 2.30. The P-value (Sig.) .115 revealed that Center had exhibited better Fetish though not significantly than their counterpart shooting guard male basketball players.

8. The mean difference between small forward and power forward male basketball players was found 2.90. The P-value (Sig.) .049 showed that the small forward male basketball players had demonstrated significantly better Fetish than their counterpart power forward male basketball players.
9. The mean difference between small forward and Center male basketball players was found 1.70. The P-value (Sig.) .242 revealed that Center had exhibited better Fetish though not significantly than their counterpart small forward male basketball players.

10. The mean difference between power forward and center male basketball players was found 4.60. The P-value (Sig.) .002 showed that the center male basketball players had demonstrated significantly better Fetish than their counterpart power forward male basketball players.

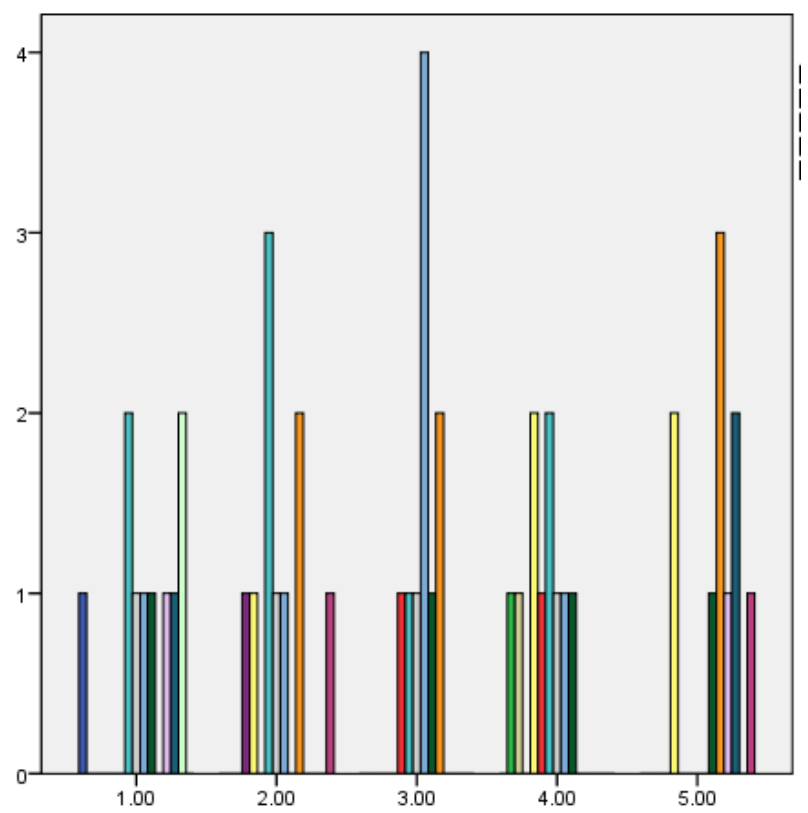

Figure 2. Graphical representation of mean scores with regard to Point Guard, Shooting Guard, Small Forward, Power Forward and Center Male Basketball Players with regard to the sub-parameter Fetish.

Table 5. Analysis of Variance (ANOVA) results among Point Guard, Shooting Guard, Small Forward, Power Forward and Center Male Basketball Players with regard to the sub-parameter Preparation.

\begin{tabular}{llllll}
\hline $\begin{array}{l}\text { Source of } \\
\text { Variation }\end{array}$ & $\begin{array}{l}\text { Sum of } \\
\text { Squares }\end{array}$ & $\begin{array}{l}\text { Degree of } \\
\text { Freedom }\end{array}$ & $\begin{array}{l}\text { Mean } \\
\text { Square }\end{array}$ & F-value & $\begin{array}{l}\text { P-value } \\
\text { (Sig.) }\end{array}$ \\
\hline $\begin{array}{l}\text { Between } \\
\text { Groups }\end{array}$ & 31.32 & 4 & 7.83 & & \\
Within Groups & 328.60 & 45 & 7.30 & 1.07 & .381 \\
Total & 359.92 & 49 & & & \\
\hline
\end{tabular}

*Significant at 0.05

Table 6. Analysis of Variance (ANOVA) results among Point Guard, Shooting Guard, Small Forward, Power Forward and Center Male Basketball Players with regard to the sub-parameter Game/ Competition.

\begin{tabular}{llllll}
\hline $\begin{array}{l}\text { Source of } \\
\text { Variation }\end{array}$ & $\begin{array}{l}\text { Sum of } \\
\text { Squares }\end{array}$ & $\begin{array}{l}\text { Degree of } \\
\text { Freedom }\end{array}$ & $\begin{array}{l}\text { Mean } \\
\text { Square }\end{array}$ & F-value & $\begin{array}{l}\text { P-value } \\
\text { (Sig.) }\end{array}$ \\
\hline $\begin{array}{l}\text { Between } \\
\text { Groups }\end{array}$ & 75.20 & 4 & 18.80 & & \\
$\begin{array}{l}\text { Within Groups } \\
\text { Total }\end{array}$ & 344.80 & 45 & 7.66 & 2.45 & .059 \\
\hline
\end{tabular}

* Significant at 0.05 
It can be seen from table-5 that insignificant differences were found with regard to the sub-parameter Preparation among basketball players (Point Guard, Shooting Guard, Small Forward, Power Forward and Center) as the P-value (Sig.) .381 was found higher than the 0.05 level of significance $(\mathrm{p}>0.05)$. Since F-value was found insignificant, therefore, there is no need to apply Post-hoc test.

It can be seen from table- 6 that insignificant differences were found with regard to the sub-parameter Game/ Competition among basketball players (Point Guard, Shooting Guard, Small Forward, Power Forward and Center) as the P-value (Sig.) 059 was found higher than the 0.05 level of significance $(p>0.05)$. Since F-value was found insignificant, therefore, there is no need to apply Post-hoc test.

Table 7. Analysis of Variance (ANOVA) results among Point Guard, Shooting Guard, Small Forward, Power Forward and Center Male Basketball Players with regard to the sub-parameter Team Ritual.

\begin{tabular}{llllll}
\hline $\begin{array}{l}\text { Source of } \\
\text { Variation }\end{array}$ & $\begin{array}{l}\text { Sum of } \\
\text { Squares }\end{array}$ & $\begin{array}{l}\text { Degree of } \\
\text { Freedom }\end{array}$ & $\begin{array}{l}\text { Mean } \\
\text { Square }\end{array}$ & F-value & $\begin{array}{l}\text { P-value } \\
\text { (Sig.) }\end{array}$ \\
\hline $\begin{array}{l}\text { Between } \\
\text { Groups }\end{array}$ & 200.60 & 4 & 50.15 & & \\
Within Groups & 393.40 & 45 & 8.74 & $5.73^{*}$ & .001 \\
Total & 594.00 & 49 & & & \\
\hline
\end{tabular}

*Significant at 0.05

Table 8. Analysis of Least Significant Difference (LSD) post hoc test among Point Guard, Shooting Guard, Small Forward, Power Forward and Center Male Basketball Players with regard to the sub-parameter Team Ritual.

\begin{tabular}{llll}
\hline Means & Mean Difference & $\begin{array}{l}\text { P-value } \\
\text { (Sig.) }\end{array}$ \\
\hline Point Guard & Shooting Guard [10.40] & .90 & .500 \\
{$[11.30]$} & Small Forward [15.80] & $-4.50^{*}$ & .001 \\
& Power Forward [10.60] & .70 & .599 \\
& Center [12.90] & -1.60 & .233 \\
Shooting & Point Guard [11.30] & -.90 & .500 \\
Guard & Small Forward [15.80] & $-5.40^{*}$ & .000 \\
{$[10.40]$} & Power Forward [10.60] & -.20 & .880 \\
& Center [12.90] & -2.50 & .065 \\
Small & Point Guard [11.30] & $4.50^{*}$ & .001 \\
Forward & Shooting Guard [10.40] & $5.40^{*}$ & .000 \\
{$[15.80]$} & Power Forward [15.00] & $5.20^{*}$ & .000 \\
& Center [12.90] & $2.90^{*}$ & .034 \\
Power & Point Guard [11.30] & -.70 & .599 \\
Forward & Shooting Guard [10.40] & .20 & .880 \\
{$[10.60]$} & Small Forward [15.80] & $-5.20^{*}$ & .000 \\
& Center [12.90] & -2.30 & .089 \\
& Point Guard [11.30] & 1.60 & .233 \\
Center & Shooting Guard [10.40] & 2.50 & .065 \\
{$[12.90]$} & Small Forward [15.80] & $-2.90^{*}$ & .034 \\
& Power Forward [10.60] & 2.30 & .089 \\
\hline \multirow{2}{*}{ Sing }
\end{tabular}

*Significant at 0.05

It can be seen from table-7 that significant differences were found with regard to the sub-parameter Team Ritual among basketball players (Point Guard, Shooting Guard, Small Forward, Power Forward and Center) as the P-value
(Sig.) .001 was found smaller than 0.05 level of significance $(p<0.05)$. Since the obtained F-value was found significant, therefore, least significant difference (LSD) Post-hoc test was employed to study the direction and significance of difference between paired means among basketball players (Point Guard, Shooting Guard, Small Forward, Power Forward and Center) on the sub-parameter Team Ritual. The results of LSD Post-hoc test have been presented in Table-8.

- It has been observed from the table- 8 that mean difference between point guard and shooting guard male basketball players was found .90. The P-value (Sig.) .500 revealed that point guard had exhibited better Team Ritual though not significantly than their counterpart shooting guard male basketball players.

- The mean difference between point guard and small forward male basketball players was found 4.50. The Pvalue (Sig.) .001 showed that the small forward male basketball players had demonstrated significantly better Team Ritual than their counterpart point guard male basketball players.

- The mean difference between point guard and power forward male basketball players was found .70. The Pvalue (Sig.) .599 revealed that point guard had exhibited better Team Ritual though not significantly than their counterpart power forward male basketball players.

- The mean difference between point guard and center male basketball players was found 1.60. The P-value (Sig.) .233 revealed that center had exhibited better Team Ritual though not significantly than their counterpart point guard male basketball players.

- The mean difference between shooting guard and small forward male basketball players was found 5.40. The Pvalue (Sig.) .000 showed that the small forward male basketball players had demonstrated significantly better Team Ritual than their counterpart shooting guard male basketball players.

- The mean difference between shooting guard and Power Forward male basketball players was found .20. The P-value (Sig.) .880 revealed that Power Forward had exhibited better Team Ritual though not significantly than their counterpart shooting guard male basketball players.

- The mean difference between shooting guard and Center male basketball players was found 2.50. The Pvalue (Sig.) 0.65 revealed that Center had exhibited better Team Ritual though not significantly than their counterpart shooting guard male basketball players.

- The mean difference between small forward and power forward male basketball players was found 5.20. The Pvalue (Sig.) .000 showed that the small forward male basketball players had demonstrated significantly better Team Ritual than their counterpart power forward male basketball players.

- The mean difference between small forward and Center male basketball players was found 2.90. The P-value (Sig.) .034 revealed that small forward had exhibited 
better Team Ritual though not significantly than their counterpart center male basketball players.

- The mean difference between power forward and center male basketball players was found 2.30. The P-value (Sig.) .089 revealed that center had exhibited better Team Ritual though not significantly than their counterpart power forward male basketball players.

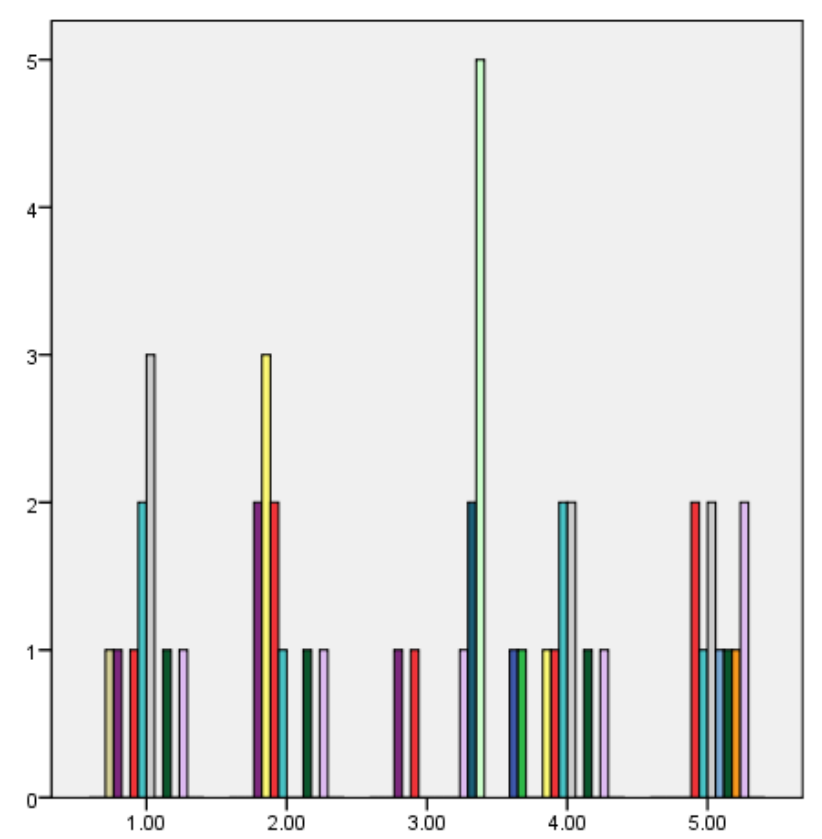

Figure 3. Graphical representation of mean scores with regard to Point Guard, Shooting Guard, Small Forward, Power Forward and Center Male Basketball Players with regard to the sub-parameter Team Ritual.

Table 9. Analysis of Variance (ANOVA) results among Point Guard, Shooting Guard, Small Forward, Power Forward and Center Male Basketball Players with regard to the sub-parameter Prayer.

\begin{tabular}{llllll}
\hline $\begin{array}{l}\text { Source of } \\
\text { Variation }\end{array}$ & $\begin{array}{l}\text { Sum of } \\
\text { Squares }\end{array}$ & $\begin{array}{l}\text { Degree of } \\
\text { Freedom }\end{array}$ & $\begin{array}{l}\text { Mean } \\
\text { Square }\end{array}$ & F-value & $\begin{array}{l}\text { P-value } \\
\text { (Sig.) }\end{array}$ \\
\hline $\begin{array}{l}\text { Between } \\
\text { Groups }\end{array}$ & 19.48 & 4 & 4.87 & & \\
Within Groups & 219.10 & 45 & 4.86 & 1.00 & .417 \\
Total & 238.58 & 49 & & & \\
\hline
\end{tabular}

*Significant at 0.05

It can be seen from table-9 that insignificant differences were found with regard to the sub-parameter Prayer among basketball players (Point Guard, Shooting Guard, Small Forward, Power Forward and Center) as the P-value (Sig.) .417 was found higher than the 0.05 level of significance $(\mathrm{p}>0.05)$. Since F-value was found insignificant, therefore, there is no need to apply Post-hoc test.

It can be seen from table-10 that insignificant differences were found with regard to the sub-parameter Coach among basketball players (Point Guard, Shooting Guard, Small Forward, Power Forward and Center) as the P-value (Sig.) .082 was found higher than the 0.05 level of significance $(p>0.05)$. Since F-value was found insignificant, therefore, there is no need to apply Post-hoc test.
Table 10. Analysis of Variance (ANOVA) results among Point Guard, Shooting Guard, Small Forward, Power Forward and Center Male Basketball Players with regard to the sub-parameter Coach.

\begin{tabular}{llllll}
\hline $\begin{array}{l}\text { Source of } \\
\text { Variation }\end{array}$ & $\begin{array}{l}\text { Sum of } \\
\text { Squares }\end{array}$ & $\begin{array}{l}\text { Degree of } \\
\text { Freedom }\end{array}$ & $\begin{array}{l}\text { Mean } \\
\text { Square }\end{array}$ & $\begin{array}{l}\text { F- } \\
\text { value }\end{array}$ & $\begin{array}{l}\text { P-value } \\
\text { (Sig.) }\end{array}$ \\
\hline $\begin{array}{l}\text { Between } \\
\text { Groups }\end{array}$ & 75.40 & 4 & 18.85 & & \\
$\begin{array}{l}\text { Within Groups } \\
\text { Total }\end{array}$ & 382.60 & 45 & 8.50 & 2.21 & .082 \\
\hline
\end{tabular}

${ }^{*}$ Significant at 0.05

Table 11. Analysis of Variance (ANOVA) results among Point Guard, Shooting Guard, Small Forward, Power Forward and Center Male Basketball Players with regard to the parameter Superstitious (Total).

\begin{tabular}{llllll}
\hline $\begin{array}{l}\text { Source of } \\
\text { Variation }\end{array}$ & $\begin{array}{l}\text { Sum of } \\
\text { Squares }\end{array}$ & $\begin{array}{l}\text { Degree of } \\
\text { Freedom }\end{array}$ & $\begin{array}{l}\text { Mean } \\
\text { Square }\end{array}$ & F-value & $\begin{array}{l}\text { P-value } \\
\text { (Sig.) }\end{array}$ \\
\hline $\begin{array}{l}\text { Between } \\
\text { Groups }\end{array}$ & 1768.28 & 4 & 442.07 & & \\
Within Groups & 4681.80 & 45 & 104.04 & $4.24^{*}$ & .005 \\
Total & 6450.08 & 49 & & & \\
\hline
\end{tabular}

${ }^{*}$ Significant at 0.05

It can be seen from table-11 that significant differences were found with regard to the parameter Superstitious (Total) among basketball players (Point Guard, Shooting Guard, Small Forward, Power Forward and Center) as the P-value (Sig.) .005 was found smaller than 0.05 level of significance $(\mathrm{p}<0.05)$.

Table 12. Analysis of Least Significant Difference (LSD) post hoc test among Point Guard, Shooting Guard, Small Forward, Power Forward and Center Male Basketball Players with regard to the parameter Superstitious (Total).

\begin{tabular}{|c|c|c|c|}
\hline Means & & $\begin{array}{l}\text { Mean } \\
\text { Difference }\end{array}$ & $\begin{array}{l}\text { P-value } \\
\text { (Sig.) }\end{array}$ \\
\hline \multirow{4}{*}{$\begin{array}{l}\text { Point Guard } \\
{[115.00]}\end{array}$} & Shooting Guard [102.10] & $12.90^{*}$ & .007 \\
\hline & Small Forward [112.10] & 2.90 & .528 \\
\hline & Power Forward [107.80] & 7.20 & .121 \\
\hline & Center [119.40] & -4.40 & .340 \\
\hline \multirow{4}{*}{$\begin{array}{l}\text { Shooting } \\
\text { Guard } \\
{[102.10]}\end{array}$} & Point Guard [115.00] & $-12.90^{*}$ & .007 \\
\hline & Small Forward [112.10] & $-10.00^{*}$ & .034 \\
\hline & Power Forward [107.80] & -5.70 & .218 \\
\hline & Center [119.40] & $-17.30^{*}$ & .000 \\
\hline \multirow{4}{*}{$\begin{array}{l}\text { Small Forward } \\
{[112.10]}\end{array}$} & Point Guard [115.00] & -2.90 & .528 \\
\hline & Shooting Guard [102.10] & $10.00^{*}$ & .034 \\
\hline & Power Forward [107.80] & 4.30 & .351 \\
\hline & Center [119.40] & -7.30 & .117 \\
\hline \multirow{4}{*}{$\begin{array}{l}\text { Power } \\
\text { Forward } \\
{[107.80]}\end{array}$} & Point Guard [115.00] & -7.20 & .121 \\
\hline & Shooting Guard [102.10] & 5.70 & .218 \\
\hline & Small Forward [112.10] & -4.30 & .351 \\
\hline & Center [119.40] & $-11.60^{*}$ & .014 \\
\hline \multirow{4}{*}{$\begin{array}{l}\text { Center } \\
{[119.40]}\end{array}$} & Point Guard [115.00] & 4.40 & .340 \\
\hline & Shooting Guard [102.10] & $17.30^{*}$ & .000 \\
\hline & Small Forward [112.10] & 7.30 & .117 \\
\hline & Power Forward [107.80] & $11.60^{*}$ & .014 \\
\hline
\end{tabular}

*Significant at 0.05

Since the obtained F-value was found significant, therefore, least significant difference (LSD) Post-hoc test was employed to study the direction and significance of 
difference between paired means among basketball players (Point Guard, Shooting Guard, Small Forward, Power Forward and Center) on the parameter Superstitious (Total). The results of LSD Post-hoc test have been presented in Table-12.

- It has been observed from the table-12 that mean difference between point guard and shooting guard male basketball players was found 12.90. The P-value (Sig.) .007 showed that the point guard male basketball players had demonstrated significantly better Superstitious (Total) than their counterpart shooting guard male basketball players.

- The mean difference between point guard and small forward male basketball players was found 2.90. The Pvalue (Sig.) .528 revealed that point guard had exhibited better Superstitious (Total) though not significantly than their counterpart small forward male basketball players.

- The mean difference between point guard and power forward male basketball players was found 7.20. The Pvalue (Sig.) .121 revealed that point guard had exhibited better Superstitious (Total) though not significantly than their counterpart power forward male basketball players.

- The mean difference between point guard and center male basketball players was found 4.40. The P-value (Sig.) .340 revealed that center had exhibited better Superstitious (Total) though not significantly than their counterpart point guard male basketball players.

- The mean difference between shooting guard and small forward male basketball players was found 10.00. The P-value (Sig.) .034 showed that the small forward male basketball players had demonstrated significantly better Superstitious (Total) than their counterpart shooting guard male basketball players.

- The mean difference between shooting guard and Power Forward male basketball players was found 5.70 The P-value (Sig.) .218 revealed that Power Forward had exhibited better Superstitious (Total) though not significantly than their counterpart shooting guard male basketball players.

- The mean difference between shooting guard and Center male basketball players was found 17.30. The Pvalue (Sig.) .000 showed that the center male basketball players had demonstrated significantly better Superstitious (Total) than their counterpart shooting guard male basketball players.

- The mean difference between small forward and power forward male basketball players was found 4.30. The Pvalue (Sig.) .351 showed that the small forward male basketball players had demonstrated significantly better Superstitious (Total) than their counterpart power forward male basketball players.

- The mean difference between small forward and Center male basketball players was found 7.30. The P-value (Sig.) .117 revealed that center had exhibited better Superstitious (Total) though not significantly than their counterpart small forward male basketball players.

- The mean difference between power forward and center male basketball players was found 11.60. The P-value (Sig.) .014 showed that the center male basketball players had demonstrated significantly better Superstitious (Total) than their counterpart power forward male basketball players.

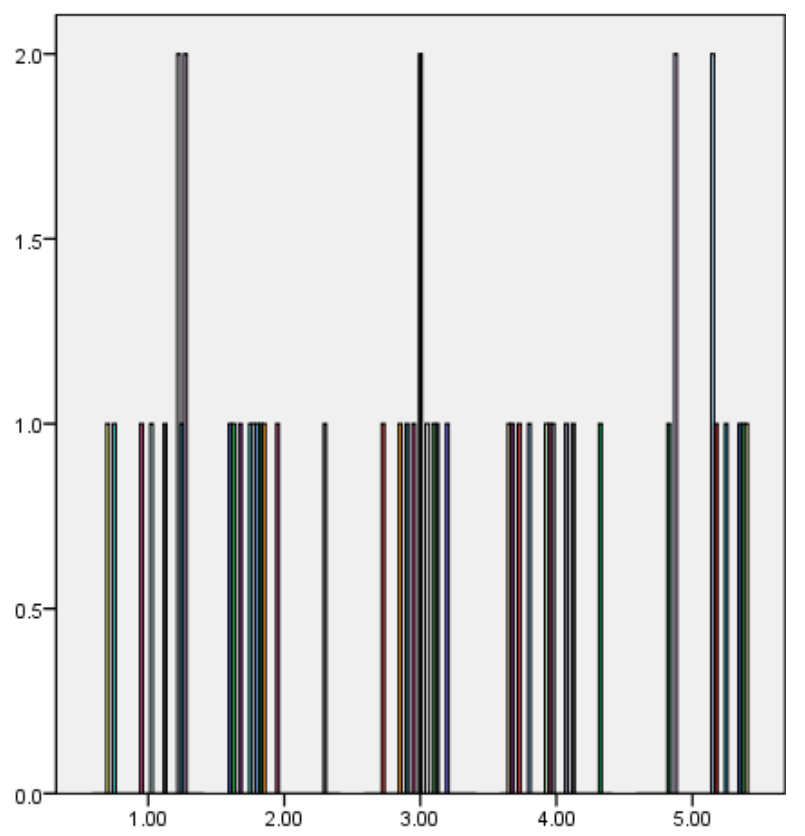

Figure 4. Graphical representation of mean scores with regard to Point Guard, Shooting Guard, Small Forward, Power Forward and Center Male Basketball Players with regard to the parameter Superstitious (Total).

Table 13. Analysis of Variance (ANOVA) results among Point Guard, Shooting Guard, Small Forward, Power Forward and Center Male Basketball Players with regard to the parameter Will to Win.

\begin{tabular}{llllll}
\hline $\begin{array}{l}\text { Source of } \\
\text { Variation }\end{array}$ & $\begin{array}{l}\text { Sum of } \\
\text { Squares }\end{array}$ & $\begin{array}{l}\text { Degree of } \\
\text { Freedom }\end{array}$ & $\begin{array}{l}\text { Mean } \\
\text { Squar } \\
\text { e }\end{array}$ & $\begin{array}{l}\text { F- } \\
\text { value }\end{array}$ & $\begin{array}{l}\text { P-value } \\
\text { (Sig.) }\end{array}$ \\
\hline $\begin{array}{l}\text { Between } \\
\begin{array}{l}\text { Groups } \\
\text { Within Groups }\end{array}\end{array}$ & 40.12 & 4 & 10.03 & & \\
Total & 203.10 & 45 & 4.51 & 2.22 & .082 \\
\hline
\end{tabular}

${ }^{*}$ Significant at 0.05

It can be seen from table-13 that insignificant differences were found with regard to the parameter Will to Win among basketball players (Point Guard, Shooting Guard, Small Forward, Power Forward and Center) as the P-value (Sig.) .082 was found higher than the 0.05 level of significance $(\mathrm{p}>0.05)$. Since F-value was found insignificant, therefore, there is no need to apply Post-hoc test.

\section{Practical Application}

The study will be considerably helpful to comprehend the Superstitions Behavior and Will to Win in Basketball Performance existing among basketball players. The sports psychologists and coaches working with these areas will 
drive benefit from the findings of the present research and they can integrate the Superstitions Behavior and Will to win variables in their training schedule from the very initial stages.

\section{Conclusion}

Summarizing from the above findings we can say that significant differences were found in basketball players Point Guard, Shooting Guard, Small Forward, Power Forward and Center on the sub-variables of Superstitions Behavior i.e., Clothing and Appearance, fetish, Team Ritual and Superstitious (Total). However, insignificant differences had been observed in the basketball players Point Guard, Shooting Guard, Small Forward, Power Forward and Center on the sub-variables of Superstitions Behavior i.e., Preparation, Game/ Competition, Prayer and Coach. Conculdingly from the above findings that insignificant differences were present in the basketball players on the variable of will to win.

\section{References}

[1] Bleak, J. L., \& Frederick, C. M. (1998). Superstitious behaviour in sport: Levels of effectiveness and determinants of use in three collegiate sports. Journal of Sport Behaviour, $21,1-15$.
[2] Brooks, M. (2009). Born believers: How your brain creates God. New Scientist Magazine, 201, 30-33.

[3] Kumar, A., \& Shukla, P. S. (1998). Psychological Consistencies within the Personality of High and Low Achieving Hockey Players. Paper Presented in the International Congress of Psychology, Montreal, Canada.

[4] Mayberry, W. (2010). Unearthing superstitions. Psychology of Sports. http://psychologyofsports.com/2010/06/08/unearthingsuperstitions/.

[5] Paul, B. W. (1960). Building a Champion Football Teams. NJ: Englewood Cliffs.

[6] Roenigk, A. (2010). The power of belief. Espn the Magazine. http://sports.espn.go.com/espn/news/story?id=5660039.

[7] Wann, D. L., Grieve, F. G., End, C., Zapalac, R. K., Lanter, J. R., Pease, D. G., \& Wallace, A. (2010). Examining the superstitious behaviors of sports fans: Types of superstitions, perceptions of impact, and relationship with team identification. Athletic Insight, 5, 21-44.

[8] Mailer, J. B., \& Lundeen, G. E. (1934).Sources of Superstitious Beliefs. Journal of Educational Research, 26(6), 321-343.

[9] Robson, D. (2005). Players Walk Fine Line when it comes to Superstitions. USA Today.

[10] Flanagan, E. (2013). Superstitious Ritual in Sport and the Competitive Anxiety Response in Elite and Non-Elite Athletes (Unpublished Bachelor's dissertation). DBS School of Arts, Dublin. 